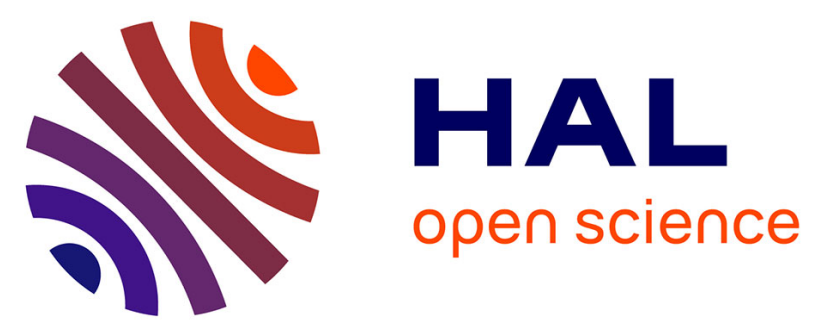

\title{
A DMAP-catalyzed mild and efficient synthesis of 1,2-dihydroquinazolines via a one-pot three-component protocol
}

Chamseddine Derabli, Raouf Boulcina, Gilbert Kirsch, Bertrand Carboni, Abdelmadjid Debache

\section{To cite this version:}

Chamseddine Derabli, Raouf Boulcina, Gilbert Kirsch, Bertrand Carboni, Abdelmadjid Debache. A DMAP-catalyzed mild and efficient synthesis of 1,2-dihydroquinazolines via a one-pot three-component protocol. Tetrahedron Letters, 2014, 55 (1), pp.200-204. 10.1016/j.tetlet.2013.10.157 . hal-00955594

HAL Id: hal-00955594

https://hal-univ-rennes1.archives-ouvertes.fr/hal-00955594

Submitted on 28 Mar 2014

HAL is a multi-disciplinary open access archive for the deposit and dissemination of scientific research documents, whether they are published or not. The documents may come from teaching and research institutions in France or abroad, or from public or private research centers.
L'archive ouverte pluridisciplinaire HAL, est destinée au dépôt et à la diffusion de documents scientifiques de niveau recherche, publiés ou non, émanant des établissements d'enseignement et de recherche français ou étrangers, des laboratoires publics ou privés. 


\title{
A DMAP-catalyzed mild and efficient synthesis of 1,2-dihydroquinazolines via a one-pot three-component protocol
}

\author{
Chamseddine Derabli, ${ }^{\mathrm{a}}$ Raouf Boulcina, ${ }^{\mathrm{a}, *}$ Gilbert Kirsch, ${ }^{\mathrm{b}}$ Bertrand Carboni, ${ }^{\mathrm{c}}$ \\ Abdelmadjid Debache ${ }^{\mathrm{a}}$ \\ ${ }^{a}$ Laboratoire de Synthèse des Molécules d'intérêts Biologiques, Université de Constantine 1, 25000 Constantine, Algérie. \\ ${ }^{b}$ SRSMC site Messin UMR 6575, Université de Lorraine, 57070 Metz, France. \\ ${ }^{c}$ Sciences Chimiques de Rennes, UMR 6226 CNRS-Université de Rennes 1, Campus de Beaulieu, 35042 Rennes Cedex, France.
}

\begin{abstract}
:
An efficient and simple method for the synthesis of 1,2-dihydroquinazolines catalyzed by 4-(N,N-dimethylamino)pyridine (DMAP) from readily available aromatic or heteroaromatic aldehydes, 2-aminobenzophenone, and ammonium acetate under mild conditions is described. The scope and limitations of the method are discussed.
\end{abstract}

Six-membered heterocycles, such as quinazolines have been reported to possess diverse biological and therapeutic properties including anti-inflammatory, ${ }^{1}$ antibacterial, ${ }^{2}$ antiplasmodial, ${ }^{3}$ antitumor, ${ }^{4}$ antimicrobial, and anti-oxidant. ${ }^{5}$ They have been also used as photochemotherapeutic agents, ${ }^{6}$ DNA-gyrase, JAK2, PDE5, and EGFR tyrosine kinase inhibitors, ${ }^{7}$ as well as $\mathrm{CB} 2$ receptor agonists. ${ }^{8}$ In addition, quinazolines are commonly found as building blocks for a wide variety of natural products such as alkaloids and in various other microorganisms including Bouchardatia neurococca, Peganum nigellastrum, Bacillus cereus, and Dichroa febrifuga. ${ }^{9}$ In a recent report, 3,4-dihydroquinazolines have been found to have excellent T-type calcium channel blocking activity. ${ }^{10}$

The development of quinazoline-based drugs has renewed the interest in developing new synthetic strategies for the synthesis of quinazolines. Numerous procedures have been reported, such as copper-catalyzed syntheses, ${ }^{11}$ photochemical methods, ${ }^{12}$ the use of microwave irradiation, ${ }^{13}$ a maltose-urea- $\mathrm{NH}_{4} \mathrm{Cl}$ mixture as a solvent without any catalyst, ${ }^{14}$ tandem reactions from 2-aminobenzophenones and benzylic amines, ${ }^{15}$ and copper-catalyzed Ullmann N-arylation coupling. ${ }^{16}$

However, only a few examples of the preparation of 1,2-dihydroquinazolines have been reported in the literature. The reaction of 2-aminobenzamidine with benzaldehyde ${ }^{17}$ or acetone ${ }^{18}$ and microwave irradiation of 2-

(aminoaryl)alkanone $O$-phenyl oximes with carbonyl compounds ${ }^{19}$ are two such methods for the generation of 1,2dihydroquinazolines. Other synthetic approaches toward 1,2-dihydroquinazolines are based on the reaction of 2aminobenzonitriles with Grignard reagents, followed by condensation with an aldehyde. ${ }^{20}$ The yield of the reaction was very poor under such conditions due to competitive side reactions. Moreover, an inert atmosphere and long reaction time were

Keywords: Multicomponent reaction; 1,2-Dihydroquinazolines; DMAP; 2-Aminobenzophenone.

* Corresponding author. Tel./ fax: +0213 318188 62; e-mail: boulcinaraouf@yahoo.fr. 
necessary. Also, 2-carboxylic acid derivatives of 1,2-dihydroquinazoline ${ }^{21}$ were synthesized from 2-hydroxyglycine and 2aminobenzophenones wherein the stabilities of the products were compromised as they tended to decompose in solution.

The reactions of 2-aminobenzophenones with various aldehydes and ammonia have been shown to result in a mixture of quinazoline and dihydroquinazoline derivatives in a variable ratio depending on the nature of the aldehydes as well as the employed reaction conditions. ${ }^{22}$ The reaction apparently suffers from disadvantages such as a lack of selectivity often leading to a mixture of products and a cumbersome work-up procedure. Therefore, improved and environmentally benign approaches that allow for the rapid, cost-effective syntheses of quinazolines from readily available precursors are desirable.

4-( $N, N$-Dimethylamino)pyridine (DMAP) has been widely used in many organic syntheses as a catalyst, for example, in acylation reactions, ${ }^{23}$ aldol reactions, ${ }^{24}$ and Baylis-Hillman reactions. ${ }^{25}$ It has been also used in Michael additions ${ }^{26}$ and esterification reactions in water. ${ }^{27}$

In the context of our studies on the development of efficient catalytic organic synthesis, ${ }^{28}$ we have focused on the utility of DMAP as a catalyst for the synthesis of a series of 1,2-dihydroquinazolines via reactions between readily available aldehydes (1), 2-aminobenzophenone (2), and ammonium acetate (3) in ethanol under mild conditions (Scheme 1).

Scheme 1. Synthesis of 1,2-dihydroquinazoline derivatives.

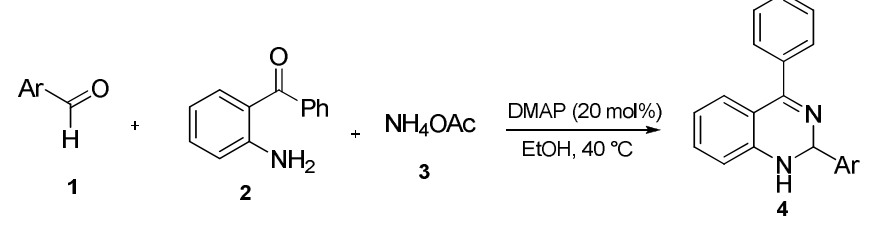

Initially, a model reaction was conducted, without any catalyst, between 4-chlorobenzaldehyde (1h) (0.5 mmol), 2aminobenzophenone (2) $(0.5 \mathrm{mmol})$, and ammonium acetate $(3)(1 \mathrm{mmol})$ in ethanol at ambient temperature for two hours, which afforded dihydroquinazoline $\mathbf{4 h}$ in moderate yield (Table 1 , entry 1 ). The same condensation was then conducted at different temperatures. Compared with the reaction at room temperature, both the yield and reaction rate were improved considerably at $40{ }^{\circ} \mathrm{C}$ (entry 2); reflux temperature was found to be less effective and the desired product was obtained in a lower yield $(68 \%)$ after one hour.

We then evaluated the effect of the solvent on this reaction. Protic solvents proved to be crucial for the reaction. The reaction carried out in pure methanol afforded the adduct $\mathbf{4 h}$ in $63 \%$ yield after one hour (Table 1, entry 4). However, no reaction was observed when other organic solvents were used. By conducting the reaction in $50 \%$ aqueous ethanol or in $\mathrm{CH}_{3} \mathrm{CN}$, the desired dihydroquinazoline $4 \mathrm{~h}$ was not formed at all, and the starting substrates were recovered (Table 1, entries 5 and 6 ). Among the solvent systems examined, we found that ethanol was the solvent of choice.

Table 1. Optimization of the reaction conditions. ${ }^{\mathrm{a}}$

\begin{tabular}{|c|c|c|c|c|c|c|}
\hline Entry & Solvent & Time (h) & Catalyst & $\begin{array}{l}\text { Catalyst } \\
(\mathrm{mol} \%)\end{array}$ & $\begin{array}{c}\text { Temperature } \\
\left({ }^{\circ} \mathrm{C}\right)\end{array}$ & $\begin{array}{c}\text { Yield }^{b} \\
(\%)\end{array}$ \\
\hline 1 & $\mathrm{EtOH}$ & 2 & - & - & $\mathrm{rt}$ & 65 \\
\hline 2 & EtOH & 1 & - & - & 40 & 78 \\
\hline 3 & $\mathrm{EtOH}$ & 1 & - & - & reflux & 68 \\
\hline 4 & $\mathrm{MeOH}$ & 1 & - & - & 40 & 63 \\
\hline 5 & $\mathrm{H}_{2} \mathrm{O}-\mathrm{EtOH}$ & 1 & - & - & 40 & - \\
\hline 6 & $\mathrm{CH}_{3} \mathrm{CN}$ & 1 & - & - & 40 & - \\
\hline 7 & $\mathrm{EtOH}$ & 2 & $\mathrm{CAN}$ & 5 & 40 & 17 \\
\hline 8 & $\mathrm{EtOH}$ & 2 & CAN & 10 & 40 & 39 \\
\hline 9 & $\mathrm{EtOH}$ & 2 & $\mathrm{PhB}(\mathrm{OH})_{2}$ & 10 & 40 & 74 \\
\hline 10 & $\mathrm{EtOH}$ & 1.5 & $\mathrm{SnCl}_{2}$ & 10 & 40 & 71 \\
\hline 11 & $\mathrm{EtOH}$ & 1.5 & $\mathrm{FeCl}_{3} \cdot 6 \mathrm{H}_{2} \mathrm{O}$ & 10 & 40 & 34 \\
\hline 12 & $\mathrm{EtOH}$ & 1.5 & DMAP & 10 & 40 & 82 \\
\hline 13 & $\mathrm{EtOH}$ & 1.5 & DMAP & 5 & 40 & 82 \\
\hline 14 & $\mathrm{EtOH}$ & 1 & DMAP & 15 & 40 & 83 \\
\hline 15 & $\mathrm{EtOH}$ & 1 & DMAP & 20 & 40 & 87 \\
\hline
\end{tabular}




\begin{tabular}{lllllll}
\hline 16 & EtOH & 1 & DMAP & 30 & 40 & 85 \\
17 & EtOH & 1.5 & DABCO & 20 & 40 & 81 \\
18 & EtOH & 1.5 & $\mathrm{Et}_{3} \mathrm{~N}$ & 20 & 40 & 65 \\
\hline
\end{tabular}

${ }^{a}$ Reaction conditions: 4-chlorobenzaldehyde (1h) $(0.5 \mathrm{mmol}), 2$-aminobenzophenone (2) $(0.5 \mathrm{mmol}), \mathrm{NH}_{4} \mathrm{OAc}(\mathbf{3})(1 \mathrm{mmol})$, solvent $(5 \mathrm{~mL}) .{ }^{\mathrm{b}}$ Isolated yield.

Various Lewis acid catalysts such as $\mathrm{CAN}, \mathrm{PhB}(\mathrm{OH})_{2}, \mathrm{SnCl}_{2}$ and $\mathrm{FeCl}_{3} \cdot 6 \mathrm{H}_{2} \mathrm{O}$ were utilized but with limited success. Among the examined catalysts, phenylboronic acid and $\mathrm{SnCl}_{2}$ exhibited relatively good catalytic activity (Table 1, entries 9 and 10). These results prompted us to examine the reaction with other catalysts such as Lewis bases. In the case of DMAP, the reaction proceeded more effectively; it was able to catalyze the reaction affording product $4 \mathrm{~h}$ in higher yields (entries 12-16). The use of DMAP (20 mol\%) gave the corresponding product in $87 \%$ yield without any side-products being detected (entry 15). The use of DABCO or triethylamine as other Brønsted base catalysts gave similar results (entries 17 and 18), but with diminished yields.

Thus, under the optimized conditions, the generality of the reaction was investigated by employing several aromatic aldehydes. The results are summarized in Table 2. In general, the reactions were rapid at $40{ }^{\circ} \mathrm{C}$ and the corresponding dihydroquinazolines were formed in $67-98 \%$ yields. The electronic nature of the substituents on the benzene ring had no significant influence on the reactivity. An unsubstituted phenyl group (Table 2, entry 1) or aryl groups with electron-donating substituents (entries 2 and 3) afforded high yields, as did those with electron-withdrawing groups. However, the presence of 2-chloro-, 4- $N, N$-dimethylamino- or 4-hydroxy- groups on the aromatic ring gave slightly diminished the yields.

Table 2. DMAP-catalyzed synthesis of 1,2-dihydroquinazolines. ${ }^{a}$

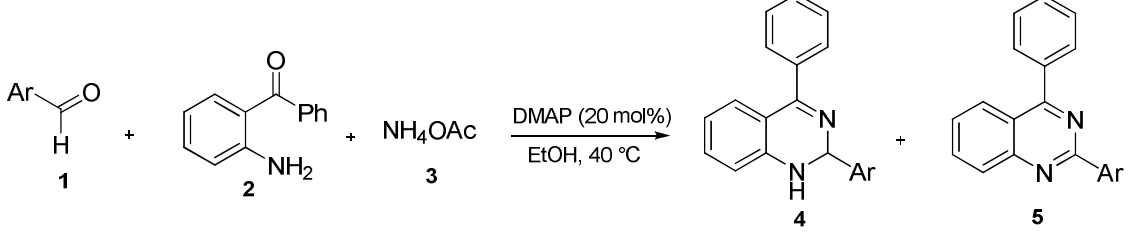

\begin{tabular}{|c|c|c|c|c|c|c|c|}
\hline \multirow{2}{*}{ Entry } & \multirow{2}{*}{$\mathrm{Ar}$} & \multirow{2}{*}{ Products } & \multirow{2}{*}{ Time (h) } & \multirow[t]{2}{*}{ Product ratio ${ }^{b}$} & \multirow{2}{*}{$\begin{array}{c}\text { Yield }^{\mathrm{c}} \\
(\%)\end{array}$} & \multicolumn{2}{|c|}{ M.p. $\left({ }^{\circ} \mathrm{C}\right)$} \\
\hline & & & & & & Measured & Reported $^{22}$ \\
\hline 1 & $\mathrm{C}_{6} \mathrm{H}_{5^{-}}$ & $4 a: 5 a$ & 1.5 & $90: 10$ & 84 & $94-96$ & $95-97$ \\
\hline 2 & 4-Me- $\mathrm{C}_{6} \mathrm{H}_{4^{-}}$ & $4 b: 5 b$ & 1 & $90: 10$ & 91 & $122-124$ & $127-129$ \\
\hline 3 & $2-\mathrm{MeO}-\mathrm{C}_{6} \mathrm{H}_{4}-$ & $4 c: 5 c$ & 1.5 & $86: 14$ & 83 & gum & - \\
\hline 4 & $4-(\mathrm{Me})_{2} \mathrm{~N}^{-} \mathrm{C}_{6} \mathrm{H}_{4}-$ & $4 d: 5 d$ & 2 & $100: 0$ & 76 & $172-174$ & - \\
\hline 5 & $\mathrm{C}_{6} \mathrm{H}_{5}-\mathrm{C}_{6} \mathrm{H}_{4^{-}}$ & $4 e: 5 e$ & 1 & $84: 16$ & 98 & $138-140$ & - \\
\hline 6 & $4-\mathrm{HO}-\mathrm{C}_{6} \mathrm{H}_{4}^{-}$ & 4f:5f & 2.5 & 99:trace & 67 & $200-202$ & - \\
\hline 7 & $2-\mathrm{Cl}-\mathrm{C}_{6} \mathrm{H}_{4}^{-}$ & $4 g: 5 g$ & 2 & 100:0 & 78 & gum & gum \\
\hline 8 & $4-\mathrm{Cl}-\mathrm{C}_{6} \mathrm{H}_{4}^{-}$ & $4 h: 5 h$ & 1 & $100: 0$ & 87 & $142-144$ & - \\
\hline 9 & $4-\mathrm{Br}-\mathrm{C}_{6} \mathrm{H}_{4^{-}}$ & $4 i: 5 i$ & 1.5 & $100: 0$ & 80 & $178-180$ & - \\
\hline 10 & $3-\mathrm{I}-\mathrm{C}_{6} \mathrm{H}_{4}-$ & $4 j: 5 j$ & 1 & $75: 25$ & 86 & $112-114$ & - \\
\hline 11 & $4-\mathrm{F}-\mathrm{C}_{6} \mathrm{H}_{4^{-}}$ & $4 k: 5 k$ & 1.5 & $90: 10$ & 80 & $126-128$ & $128-130$ \\
\hline 12 & $3-\mathrm{O}_{2} \mathrm{~N}-\mathrm{C}_{6} \mathrm{H}_{4}-$ & 4l:5l & 1 & $100: 0$ & 87 & $134-136$ & - \\
\hline
\end{tabular}

${ }^{a}$ Reaction conditions: aldehyde (1) $(0.5 \mathrm{mmol}), 2$-aminobenzophenone (2) $(0.5 \mathrm{mmol}), \mathrm{NH}_{4} \mathrm{OAc}(3)(1 \mathrm{mmol}), \mathrm{DMAP}(0.1 \mathrm{mmol}), \mathrm{EtOH}(5 \mathrm{~mL}), 40{ }^{\circ} \mathrm{C}$.

${ }^{\mathrm{b}}$ Ratios were determined from the ${ }^{1} \mathrm{H}$ NMR spectra of the mixtures. ${ }^{\mathrm{c}}$ Isolated yield of pure 1,2-dihydroquinazoline.

Next, we were interested in applying this protocol to other starting materials. Therefore, a variety of heterocyclic aldehydes were reacted in a similar manner with 2-aminobenzophenone and ammonium acetate. As a result, differently substituted dihydroquinazolines were obtained in moderate to good yields ranging from 68 to $98 \%$ (Table 3, entries 1-4). The use of the isatin also gave the corresponding product in good yield (entry 5).

In order to evaluate further the efficiency of this protocol, 2-aminoacetophenone was subjected to the reaction with benzaldehyde and $\mathrm{NH}_{4} \mathrm{OAc}$ in the presence of $20 \mathrm{~mol} \%$ of DMAP under the same conditions described above. Unfortunately, the reaction provided a mixture of products accompanied by unreacted starting materials, and we were not able to isolate the desired 1,2-dihydroquinazoline.

In all cases, we obtained 1,2-dihydroquinazolines in high yields as the major product with only a small amount of the oxidized form. The quantity of this minor product was increased by allowing the dihydroquinazolines to stand in air for a few hours. To prevent aromatization, it was necessary to store the products under an inert atmosphere. The other product ratios are listed in Tables 2 and 3. 
Based on the above observations, we propose two plausible mechanistic pathways for the present protocol in which we believe that DMAP acts as a base. ${ }^{29}$ The first reaction mechanism (path a) is proposed to proceed via the condensation of the aldehyde (1) with 2-aminobenzophenone (2) to furnish the corresponding aldimine $\mathbf{A}$. Further condensation of this intermediate with ammonium acetate gives diimine $\mathbf{B}$ which was isolated and identified by ${ }^{1} \mathrm{H}$ NMR spectroscopy. Deprotonation of $\mathbf{B}$ with the catalyst produces carbanion intermediate $\mathbf{C}$, which undergoes intramolecular cyclization to form the target 1,2-dihydroquinazoline 4, which can be aromatized by air to give the corresponding quinazoline $\mathbf{5}$ as a minor product.

In another possible mechanism (path b), the condensation of aldehyde (1) with $\mathrm{NH}_{4} \mathrm{OAc}$ results in the formation of aldimine $\mathbf{D}$, the further reaction of which with 2-aminobenzophenone (2) leads, after dehydration, to the desired product 4 . The proposed mechanisms are shown in Scheme 2.

Scheme 2. Proposed mechanisms for the synthesis of 1,2-dihydroquinazolines 4.

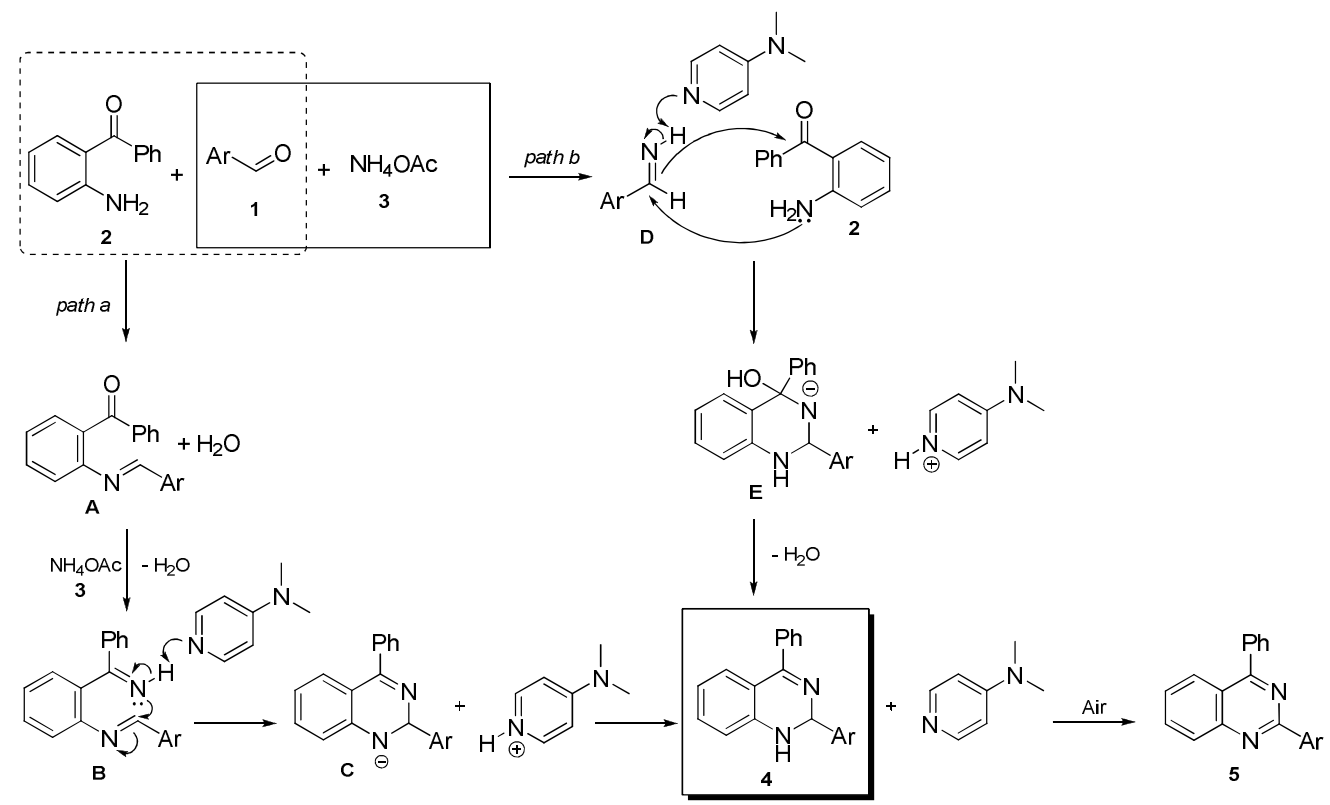

It is important to note that with the exception of compounds $4 \mathbf{c}, \mathbf{4 g}, \mathbf{4 m}$ and $\mathbf{4 p}$, which were isolated by pouring the reaction mixtures onto cold water, followed by extraction with ethyl acetate, evaporation and then flash column chromatography on silica gel using EtOAc/hexane (1:3) as the eluent, all the other dihydroquinazolines were recrystallized to provide the desired products in pure form. ${ }^{30}$

DMAP is more soluble in water than in organic solvents and it could be recovered almost quantitatively from the aqueous layer.

The structures of the products were confirmed by FT-IR, ${ }^{1} \mathrm{H},{ }^{13} \mathrm{C}$ NMR, HRMS, and elemental analysis.

Table 3. DMAP-catalyzed synthesis of 1,2-dihydroquinazolines from heterocyclic aldehydes or diketones. ${ }^{\text {a }}$

\begin{tabular}{|c|c|c|c|c|c|c|c|}
\hline \multirow{2}{*}{ Entry } & \multirow{2}{*}{ ArCHO or diketone } & \multirow{2}{*}{ Products } & \multirow{2}{*}{ Time $(\mathrm{h})$} & \multirow{2}{*}{ Product ratio $^{b}$} & \multirow{2}{*}{$\begin{array}{c}\text { Yield }^{\mathrm{c}} \\
(\%)\end{array}$} & \multicolumn{2}{|c|}{ M.p. $\left({ }^{\circ} \mathrm{C}\right)$} \\
\hline & & & & & & Measured & Reported $^{21}$ \\
\hline 1 & Ar $=2$-thienyl & $4 m: 5 m$ & 2.5 & $85: 15$ & 68 & gum & gum \\
\hline 2 & $\mathrm{Ar}=4$-quinolyl & $4 n: 5 n$ & 2 & $90: 10$ & 94 & $218-220$ & - \\
\hline 3 & $\mathrm{Ar}=2-(\mathrm{Cl})-8-(\mathrm{Me})-3$-quinolyl & $40: 50$ & 2 & 100:0 & 85 & $182-184$ & - \\
\hline 4 & $\mathrm{Ar}=2-(\mathrm{Cl})-6-(\mathrm{OMe})-3$-quinolyl & $4 p: 5 p$ & 1.5 & $82: 18$ & 98 & gum & - \\
\hline 5 & & $4 q: 5 q$ & 4 & 99:trace & 78 & $144-146$ & $142-145$ \\
\hline
\end{tabular}

${ }^{a}$ Reaction conditions: aldehyde or diketone (0.5 mmol), 2-aminobenzophenone (2) (0.5 mmol), NH $\mathrm{NAc}_{4}$ (3) (1 mmol), DMAP (0.1 mmol), EtOH (5 mL), $40{ }^{\circ} \mathrm{C}$. ${ }^{b}$ Ratios were determined from the ${ }^{1} \mathrm{H}$ NMR spectra of the mixtures. ${ }^{\mathrm{c}}$ Isolated yield of pure 1,2-dihydroquinazoline.

In summary, we have succeeded in developing an efficient, general, and one-pot procedure for the synthesis of 1,2dihydroquinazoline derivatives through the DMAP-catalyzed reaction of 2-aminobenzophenone with aromatic or 
heteroaromatic aldehydes and ammonium acetate. This method offers several advantages such as high selectivity, mild reaction conditions, and easily accessible starting materials.

\section{References and notes}

1. (a) Balakumar, C.; Lamba, P.; Kishore, D. P.; Narayana, B. L.; Rao, K. V.; Rajwinder, K.; Rao, A. R.; Shireesha, B.; Narsaiah, B. Eur. J. Med. Chem. 2010, 45, 4904; (b) Alafeefy, A. M.; Kadi, A. A.; Al-Deeb, O. A.; El-Tahir, K. E. H.; Al-Jaber, N. A. Eur. J. Med. Chem. 2010, 45, 4947.

2. Tiwari, R.; Chhabra, G. Asian. J. Chem. 2010, 22, 5981.

3. Kabri, Y.; Azas, N.; Dumetre, A.; Hutter, S.; Laget, M.; Verhaeghe, P.; Gellis, A.; Vanelle, P. Eur. J. Med. Chem. $2010,45,616$.

4. (a) Noolvi, M. N.; Patel, H. M.; Bhardwaj, V.; Chauhan, A. Eur. J. Med. Chem. 2011, 46, 2327; (b) El-Azab, A. S.; Al-Omar, M. A.; Abdel-Aziz, A. A. M.; Abdel-Aziz, N. I.; El-Sayed, M. A. A.; Aleisa, A. M.; Sayed-Ahmed, M. M.; Abdel-Hamide, S. G. Eur. J. Med. Chem. 2010, 45, 4188.

5. $\quad$ Kumar, A.; Sharma, P.; Kumari, P.; Kalal, B. L. Bioorg. Med. Chem. Lett. 2011, 21, 4353.

6. $\quad$ Barraja, P.; Caracausi, L.; Diana, P.; Montalbano, A.; Carbone, A.; Salvador, A.; Brun, P.; Castagliuolo, I.; Tisi, S.; Dall'Acqua, F.; Vedaldi, D.; Cirrincione, G. Chem. Med. Chem. 2011, 6, 1238.

7. (a) Boyapati, S.; Kulandaivelu, U.; Sangu, S.; Vanga, M. R. Arch. Pharm. 2010, 343, 570; (b) Yang, S. H.; Khadka, D. B.; Cho, S. H.; Ju, H. K.; Lee, K. Y.; Han, H. J.; Lee, K. T.; Cho, W. J. Bioorg. Med. Chem. 2011, 19, 968; (c) Kim, Y. H.; Choi, H.; Lee, J.; Hwang, I. C.; Moon, S. K.; Kim, S. J.; Lee, H. W.; Im, D. S.; Lee, S. S.; Ahn, S. K.; Kim, S. W.; Han, C. K.; Yoon, J. H.; Lee, K. J.; Choi, N. S. Bioorg. Med. Chem. Lett. 2008, 18, 6279; (d) Cruz-Lopez, O.; Conejo-Garcia, A.; Nunez, M. C.; Kimatrai, M.; GarciaRubino, M. E.; Morales, F.; Gomez-Perez, V.; Campos, J. M. Curr. Med. Chem. 2011, 18, 943.

8. $\quad$ Saari, R.; Törmä, J.-C.; Nevalainen, T. Bioorg. Med. Chem. 2011, 19, 939.

9. (a) Yoshida, S.; Aoyagi, T.; Harada, S.; Matsuda, N.; Ikeda, T.; Naganawa, H.; Hamada, M.; Takeuchi, T. J. Antibiot. 1991, 44, 111; (b) Wattanapiromsakul, C.; Forster, P. I.; Waterman, P. G. Phytochemistry 2003, 64, 609; (c) Deng, Y.; Xu, R.; Ye, Y. J. Chin. Pharm. Sci. 2000, 9, 116; (d) Ma, Z.-Z.; Hano, Y.; Nomura, T. Chen, Y.-J. Heterocycles 1997, 46, 541.

10. Seo, H. N.; Choi, J. Y.; Choe, Y. J.; Kim, Y.; Rhim, H.; Lee, S. H.; Kim, J.; Joo, D. J.; Lee, J. Y. Bioorg. Med. Chem. Lett. 2007, 17, 5740 .

11. (a) Huang, C.; Fu, Y.; Fu, H.; Jiang, Y. Y.; Zhao, Y. F.; Chem. Commun. 2008, 6333; (b) Ohta, Y.; Tokimizu, Y.; Oishi, S.; Fujii, N.; Ohno, H. Org. Lett. 2010, 12, 3963.

12. Alonso, R.; Caballero, A.; Campos, P. J.; Sampedro, D.; Rodriguez, M. A. Tetrahedron 2010, 66, 4469.

13. (a) Kumar, V.; Mohan, C.; Gupta, M.; Mahajan, M. P.; Tetrahedron 2005, 61, 3533; (b) Portela-Cubillo, F.; Scott, J. S.; Walton, J. C. Chem. Commun. 2008, 2935; (c) Portela-Cubillo, F.; Scott J. S.; Walton, J. C. J. Org. Chem. 2009, 74, 4934.

14. Zhang, Z-H.; Zhang, X-N.; Mo, L-P.; Li Y-X.; Ma, F-P. Green Chem. 2012, 14, 1502.

15. (a) Zhang, J. T.; Zhu, D. P.; Yu, C. M.; Wan C. F.; Wang, Z. Y. Org. Lett. 2010, 12, 2841; (b) Han, B.; Wang, C.; Han, R. F.; Yu, W.; Duan, X. Y.; Fang R.; Yang, X. L. Chem. Commun. 2011, 47, 7818; (c) Zhang, J. T.; Yu, C. M.; Wang, S. J.; Wan C. F.; Wang, Z. Y. Chem. Commun. 2010, 46, 5244. (d) Karnakar, K.; Shankar, J.; Murthy, S. N.; Ramesh K.; Nageswar, Y. V. D. Synlett 2011, 1089.

16. (a) Truong V. L.; Morrow, M.; Tetrahedron Lett. 2010, 51, 758; (b) Qiu, D.; Mo, F. Y.; Zheng, Z. T.; Zhang Y.; Wang, J. B. Org. Lett. 2010, 12, 5474.

17. Finch, N.; Gschwend, H. W. J. Org. Chem. 1971, 36, 1463.

18. Carrington, H. C. J. Chem. Soc. 1955, 2527.

19. Portela, C. F. Scott, J. S.; Walton, J. C. Chem. Commun. 2008, 2935.

20. (a) Bergman, J.; Brynolf, A.; Elman B.; Vuorinen, E. Tetrahedron 1986, 42, 3697; (b) Strekowski, L.; Cegla, M. T.; Harden, D. B.; Mokrosz J. L.; Mokrosz, M. J. Tetrahedron Lett. 1988, 29, 4265.

21. Hoefnagel, A. J.; van Koningsveld, H.; van Meurs, F.; Peters, J. A.; Sinnema A.; van Bekkum, H. Tetrahedron $1993,49,6899$.

22. Rupam, S.; Dipak, P. Green Chem. 2011, 13, 718.

23. (a) Ragnarsson, U.; Grehn, L. Acc. Chem. Res. 1998, 31, 494; (b) Wang, Y.-Z.; Kataeva, O.; Metz, P. Adv. Synth. Catal. 2009, 351, 2075 .

24. Hagiwara, H.; Inoguchi, H.; Fukushima, M.; Hoshi, T.; Suzuki, T. Tetrahedron Lett. 2006, 47, 5371.

25. Zhao, G.-L.; Huang, J. W.; Shi, M. Org. Lett. 2003, $24,4737$.

26. Ko, K.; Nakano, K.;Watanabe, S.; Ichikawa, Y.; Kotsuki, H. Tetrahedron Lett. 2009, 50, 4037.

27. Sakakura, A.; Kawajiri, K.; Ohkubo, T.; Kosugi, Y.; Ishihara, K. J. Am. Chem. Soc. 2007, 129, 14775.

28. (a) Debache, A.; Boulcina, R.; Belfaitah, A.; Rhouati, S.; Carboni, B. Synlett 2008, 509; (b) Debache A.; Ghalem W.; Boulcina, R.; Belfaitah, A.; Rhouati, S.; Carboni, B. Tetrahedron Lett. 2009, 50, 5248; (c) Debache, A.; Ghalem, W.; Boulcina, R.; Belfaitah, A.; Rhouati, S.; Carboni, B. Lett. Org. Chem. 2010, 7, 272; (d) Nemouchi, S.; Boulcina, R.; Carboni, B.; Debache, A. Comp. Rend. Chim. 2012, 15, 394; (e) Ghalem, W.; Boulcina, R.; Debache, A. Chin. J. Chem. 2012, 30, 733.

29. Davoodnia, A.; Bakavoli, M.; Soleimany, M.; Behmadi, H. Chin. Chem. Lett. 2008, 19, 685.

30. General procedure for the synthesis of 2-aryl-4-phenyl-1,2-dihydroquinazolines (4): A mixture of an aldehyde (1) (1.0 equiv), 2aminobenzophenone (2) (1.0 equiv), $\mathrm{NH}_{4} \mathrm{OAc}$ (3) (2.0 equiv), and DMAP (0.2 equiv.) in absolute $\mathrm{EtOH}(5 \mathrm{ml})$ was stirred at $40{ }^{\circ} \mathrm{C}$ for the stipulated period of time (see Tables 2 and 3). After completion of the reaction, as monitored by TLC, the mixture was poured into ice-cold $\mathrm{H}_{2} \mathrm{O}$ and the solid product was filtered, washed with $\mathrm{H}_{2} \mathrm{O}(3-5 \mathrm{~mL})$ and dried. The crude product was recrystallized from 
EtOAc to give pure dihydroquinazolines. For compounds $\mathbf{4 c}, \mathbf{4 g}, \mathbf{4 m}$ and $\mathbf{4 p}$, after cooling, $\mathrm{H}_{2} \mathrm{O}$ was added and the product was extracted with EtOAc $(3 \times 15 \mathrm{~mL})$. The combined organic extract was washed with $\mathrm{H}_{2} \mathrm{O}$, dried (anhyd $\left.\mathrm{Na}_{2} \mathrm{SO}_{4}\right)$ and the solvent removed followed by flash column chromatography over silica gel (60-120 mesh) to furnish the desired product.

Selected spectroscopic data: 2-(4-Chlorophenyl)-4-phenyl-1,2-dihydroquinazoline (4h). Yellow solid; m.p. 142-144 ${ }^{\circ} \mathrm{C}$; IR (KBr) $v$ 3320, 2364 1620, 1537, 1486, 1321, 1263, 1155, 1015, 964, 805, 741, $697 \mathrm{~cm}^{-1} ;{ }^{1} \mathrm{H} \mathrm{NMR}\left(\mathrm{CDCl}_{3}, 400 \mathrm{MHz}\right) \delta 7.72-7.61(\mathrm{~m}, 5 \mathrm{H}$, arom.), 7.49-7.36 (m, 4H, arom.), 7.32-7.21 (m, 2H, arom.), $6.77(\mathrm{td}, J=8.0,1.0 \mathrm{~Hz}, 1 \mathrm{H}$, arom.), $6.72(\mathrm{~d}, J=8.0 \mathrm{~Hz}, 1 \mathrm{H}), 6.02(\mathrm{~s}, 1 \mathrm{H}$, $\mathrm{CH}), 4.38(\mathrm{~s}, 1 \mathrm{H}, \mathrm{NH}) ;{ }^{13} \mathrm{C} \mathrm{NMR}\left(\mathrm{CDCl}_{3}, 100 \mathrm{MHz}\right) \delta 165.8,146.9,141.5,141.4,140.9,138.1,132.9,130.2,129.4,129.3,129.1$, 128.1, 127.8, 127.5, 127.3, 127.2, 118.3, 117.9, 114.3, 72.4. Anal. calcd for $\mathrm{C}_{20} \mathrm{H}_{15} \mathrm{~N}_{2} \mathrm{Cl}$ : C, 75.35; H, 4.74; N, 8.79; Found: C, 75.42; $\mathrm{H}$, 5.05; N, 9.03. HRMS calcd for $\mathrm{C}_{20} \mathrm{H}_{16} \mathrm{~N}_{2} \mathrm{Cl}\left(\mathrm{MH}^{+}\right)$319.0924; found 319.0863. 2-(2-Chloro-8-methylquinolin-3-yl)-4-phenyl-1,2dihydroquinazoline (4o). Yellow solid; m.p. 182-184 ${ }^{\circ} \mathrm{C}$; IR (KBr) v 3329, 1605, 1551, 1470, 1315, 1080, 756, $698 \mathrm{~cm}^{-1}$; ${ }^{1} \mathrm{H} \mathrm{NMR}$ $\left(\mathrm{CDCl}_{3}, 250 \mathrm{MHz}\right) \delta 8.52(\mathrm{~s}, 1 \mathrm{H}$, arom.), 7.74-7.41 (m, $8 \mathrm{H}$, arom.), 7.34-7.26 (m, 2H, arom.), 6.83-6.74 (m, 2H, arom.), $6.48(\mathrm{~s}, 1 \mathrm{H}$, $\mathrm{CH}), 4.79(\mathrm{~s}, 1 \mathrm{H}, \mathrm{NH}), 2.81\left(\mathrm{~s}, 3 \mathrm{H}, \mathrm{CH}_{3}\right) ;{ }^{13} \mathrm{C} \mathrm{NMR}\left(\mathrm{CDCl}_{3}, 62.5 \mathrm{MHz}\right) \delta 167.4,148.2,146.8,146.6,139.3,138.0,136.4,133.2$, 132.6, 130.9, 129.9, 129.3, 123.0, 128.4, 127.5, 127.1, 126.1, 120.4, 118.9, 117.9, 114.8, 68.8, 18.0. Anal. calcd for $\mathrm{C}_{24} \mathrm{H}_{18} \mathrm{~N}_{3} \mathrm{Cl}: \mathrm{C}_{\text {, }}$ 75.09; H, 4.73; N, 10.95; Found: C, 75.18; H, 4.94; N, 11.37. HRMS calcd for $\mathrm{C}_{24} \mathrm{H}_{19} \mathrm{~N}_{3} \mathrm{Cl}\left(\mathrm{MH}^{+}\right) 384.1189$; found 384.1162 . 